\title{
Evidence for Systemic Infection by Puccinia horiana, Causal Agent of Chrysanthemum White Rust, in Chrysanthemum
}

\author{
M. R. Bonde, C. A. Murphy, G. R. Bauchan, D. G. Luster, C. L. Palmer, S. E. Nester, J. M. Revell, and D. K. Berner
}

First, fourth, sixth, and eighth authors: U.S. Department of Agriculture (USDA)-Agricultural Research Service (ARS), 1301 Ditto Ave., Fort Detrick, MD 21702; second and third authors: USDA-ARS, Beltsville Agricultural Research Center, West, Beltsville, MD 20705; and fifth and seventh authors: IR-4 Project, Rutgers University, Princeton, NJ 08520.

Accepted for publication 24 July 2014.

\begin{abstract}
Bonde, M. R., Murphy, C. A., Bauchan, G. R., Luster, D. G., Palmer, C. L., Nester, S. E., Revell, J. M., and Berner, D. K. 2015. Evidence for systemic infection by Puccinia horiana, causal agent of chrysanthemum white rust, in chrysanthemum. Phytopathology 105:91-98.

Puccinia horiana, causal agent of the disease commonly known as chrysanthemum white rust (CWR), is a quarantine-significant fungal pathogen of chrysanthemum in the United States and indigenous to Asia. The pathogen was believed to have been eradicated in the United States but recently reappeared on several occasions in northeastern United States. The objective of the study presented here was to determine whether $P$. horiana could systemically infect chrysanthemum plants, thus providing a means of survival through winters. Scanning and transmission electron microscopy revealed the development of $P$. horiana on the surface and within leaves, stems, or crowns of inoculated chrysanthemum plants artificially exposed to northeastern U.S. winter temperatures.

P. horiana penetrated leaves directly through the cuticle and then colonized the mesophyll tissue both inter- and intracellularly. An electrondense material formed at the interface between fungal and host mesophyll cells, suggesting that the pathogen adhered to the plant cells. $P$. horiana appeared to penetrate mesophyll cell walls by enzymatic digestion, as indicated by the absence of deformation lines in host cell walls at penetration sites. The fungus was common in vascular tissue within the infected crown, often nearly replacing the entire contents of tracheid cell walls. $P$. horiana frequently passed from one tracheid cell to an adjacent tracheid cell by penetration either through pit pairs or nonpitted areas of the cell walls. Individual, presumed, fungal cells in mature tracheid cells of the crown and stems arising from infected crowns suggested that the pathogen might have been moving at least partially by means of the transpiration stream. The demonstration that chrysanthemum plants can be systemically infected by $P$. horiana suggests that additional disease control measures are required to effectively control CWR.
\end{abstract}

Indigenous to Asia (18), Puccinia horiana Henn., causal agent of chrysanthemum white rust (CWR), is a quarantine-significant fungal pathogen in the United States (4). P. horiana first was discovered in Japan in 1895 and described by Hennings (17) in 1901. It has been reported from several European countries (1), the United Kingdom (1), New Zealand (14), South Africa (14), Australia (13), and South America (11). In 1977, the disease was discovered for the first time in the United States (24).

By the late 1970s, CWR was considered to have been eradicated in the United States but reappeared in the states of Washington and Oregon in 1990 (15). In each instance, the disease was detected in hobbyist plantings and quickly eradicated (5). However, in 1991 and 1992, CWR again was discovered in the United States, this time in several counties in California, causing considerable concern to the nursery industry (7-9). As a result, the USDA-ARS, Foreign Disease-Weed Science Research Unit, Fort Detrick, MD, in cooperation with the Animal and Plant Health Inspection Service (APHIS), Plant Pathogen Quarantine (PPQ), conducted a study to develop a treatment protocol to control the disease (5). From that research, the systemic fungicide myclobutanil was shown to have high curative properties and was adopted by APHIS as a mandatory method to control the disease, if discovered (5).

For the next several years, CWR was believed to have been controlled, but it recently has reappeared at an increasing fre-

Corresponding author: M. R. Bonde; E-mail address: Morris.bonde@ars.usda.gov

http://dx.doi.org/10.1094/PHYTO-09-13-0266-R

This article is in the public domain and not copyrightable. It may be freely reprinted with customary crediting of the source. The American Phytopathological Society, 2015. quency (19,23). Kim et al. (19) in 2011 and O'Keefe and Davis (23) in 2012 independently provided evidence that the pathogen had survived through the winter in Pennsylvania.

$P$. horiana is an autoecious microcyclic rust fungus, completing its life cycle on a single host species. Although the pathogen can infect more than 10 chrysanthemum species, it is best known as a pathogen of Chrysanthemum $\times$ morifolium, florists' chrysanthemum. The pathogen produces two spore types (14). The basidiospore is the primary infectious propagule, arising from germinating teliospores embedded in infected leaves (14). The amount of sporulation can be extremely high, causing pustules to turn white, hence the name of the disease. Basidiospores are considered to be extremely susceptible to desiccation and have been observed to survive less than $5 \mathrm{~min}$ at $80 \%$ relative humidity $(\mathrm{RH})$ and less than $1 \mathrm{~h}$ at $90 \% \mathrm{RH}(14)$.

Teliospores of $P$. horiana have been shown to survive up to 8 weeks in detached leaves at $50 \% \mathrm{RH}$ and for shorter durations at higher relative humidities (14). When buried in compost, they survived for a maximum of 2 weeks (14).

Recently we conducted a study that showed that teliospores survived in a growth chamber simulating winter temperature conditions for a maximum of 35 days, a period insufficient for survival through typical northeastern U.S. winters (4). As a result, we decided to examine the possibility that the pathogen might survive in underground parts of systemically infected plants. Chrysanthemum plants were inoculated and placed in a growth chamber progressively simulating, at an accelerated rate, changing fall, winter, and spring temperatures in northeastern United States. This manuscript describes the development of the pathogen on and in infected plants as observed by light microscopy and scanning and transmission electron microscopy. 


\section{MATERIALS AND METHODS}

Pathogen and host. The chrysanthemum cultivar Vicki was used throughout the study. $P$. horiana isolates used in the study were all received from cooperators in 2011 and designated PA11-1 and PA11-4 from Pennsylvania and CT11-4 from Connecticut. Each was maintained by periodic inoculation of 1-month-old Vicki plants grown from cuttings. Plants periodically were fertilized with Osmocote 14-14-14. Throughout the study, all isolates behaved the same in terms of aggressiveness and morphology.

Inoculation and maintenance of plants. Plants were inoculated by placing them alongside infected "donor" plants inside a mist chamber $(1.15 \mathrm{~m}$ long $\times 0.84 \mathrm{~m}$ wide $\times 0.95 \mathrm{~m}$ high $)$ that provided a fine mist and chamber RH of $100 \%$ (4). The use of the mist chamber provided the appropriate amount of sporulation on donor plants, distribution of basidiospore inoculum, and initiation of infection on recipient test plants.

After $24 \mathrm{~h}$ in the mist chamber, inoculated plants were transferred to benches in the greenhouse at 22 to $26^{\circ} \mathrm{C}$ and later examined for symptoms of CWR. Rust pustules appeared beginning approximately 7 days after inoculation. From $24 \mathrm{~h}$ up to 36 days after inoculation, leaves were excised from inoculated and control plants. These were used to determine development of the pathogen on the surface of leaves of inoculated plants by means of scanning electron microscopy (SEM), and within infected leaves by transmission electron microscopy (TEM) and light microscopy.

Overwintering. A second set of plants was inoculated as described above and placed in the greenhouse at 22 to $26^{\circ} \mathrm{C}$. After 3 weeks, infected and control (noninoculated) plants were transferred to a growth chamber progressively simulating fall, winter, and spring temperature conditions, at an accelerated rate, in State College, PA. State College had been selected because of a report that $P$. horiana had survived through a winter at that location (23). While in the growth chamber, the diurnal temperature highs and lows followed a pattern based on average daily temperature highs and lows over a 10-year period in State College, PA. They began with September temperatures of $24^{\circ} \mathrm{C}$ daily highs $/ 13^{\circ} \mathrm{C}$ daily lows, gradually dropped to $-1{ }^{\circ} \mathrm{C}$ daily highs $/-9^{\circ} \mathrm{C}$ daily lows in January, and finally rose to $15^{\circ} \mathrm{C}$ daily highs $/ 3^{\circ} \mathrm{C}$ daily lows in April, when they were transferred to the greenhouse at 22 to $26^{\circ} \mathrm{C}$. While in the growth chamber, the plants were watered weekly to bring each pot with plant up to $1,400 \mathrm{~g}$. Watering ceased when the soil was frozen.
Three days after the plants were moved to the greenhouse, all 24 plants were incubated $24 \mathrm{~h}$ in a mist chamber along with six young sentinel plants to see if any viable teliospores were present on the overwintered plants. None of the sentinel plants developed pustules, thus demonstrating absence of viable spores.

Four of the overwintered plants developed pustules on "new" leaves, one plant at 5, 9, 16, and 30 days, respectively, after being moved to the greenhouse. (The infected leaves appeared on a total of three stems arising from parent crowns below the soil surface and on "new" leaves arising from one shoot growing from an overwintered stem.) The stem, which emerged from below the soil surface 30 days after transfer to the greenhouse, and its parent crown were selected for histological examination by TEM. The remaining new stems and parent crowns were used for light microscopy.

SEM. Excised leaves from plants that had not been subjected to winter temperatures were cut into approximately $1-\mathrm{mm}^{2}$ pieces and placed in small wire baskets $24 \mathrm{~h}$ up to 36 days after inoculation. The baskets were submerged in $3 \%$ glutaraldehyde/ cacolate buffer to fix the leaf tissue. This was followed by washing sections in a $\mathrm{Na}$ cacodylate buffer rinse, six times over $1 \mathrm{~h}$, dehydration in an $\mathrm{EtOH}$ series, and critical point drying (Tousimis Research Corp., Rockville, MD). Leaf specimens were observed using an S-4700 field emission scanning electron microscope (Hitachi High Technologies America, Inc., Dallas, TX). Specimens were secured to copper plates $(15 \times 30 \mathrm{~cm})$ using ultrasmooth, round (12-mm diameter) carbon adhesive tabs (Electron Microscopy Sciences, Inc., Hatfield, PA). The specimens were transferred to a Quorum PP2000 prep chamber (Quorum Technologies, East Sussex, UK), where they were coated with a 10 -nm layer of platinum using a magnetron sputter head equipped with a platinum target and transferred to the SEM stage with observations made at an accelerating voltage of $5 \mathrm{kV}$. Images were captured using a 4pi Analysis System (Durham, NC). Micrographs were sized and placed together to produce a single figure using Adobe Photoshop CS 5.0.

Transmission electron microscopy. The selected infected stem and parent crown from the overwintering experiment were cut into $1-\mathrm{mm}^{2}$ sections. These were placed into wire baskets and fixed by submerging in $3 \%$ glutaraldehyde/cacolate buffer as above. After the plant tissues had been in the fixative for $2 \mathrm{~h}$ at room temperature, the sections were placed overnight in a refrigerator at $4^{\circ} \mathrm{C}$. This was followed by washing sections in a $\mathrm{Na}$ cacodylate buffer rinse, six times over $1 \mathrm{~h}$, postfixing in $2 \%$ buffered osmium tetroxide for $2 \mathrm{~h}$, dehydration in an ETOH
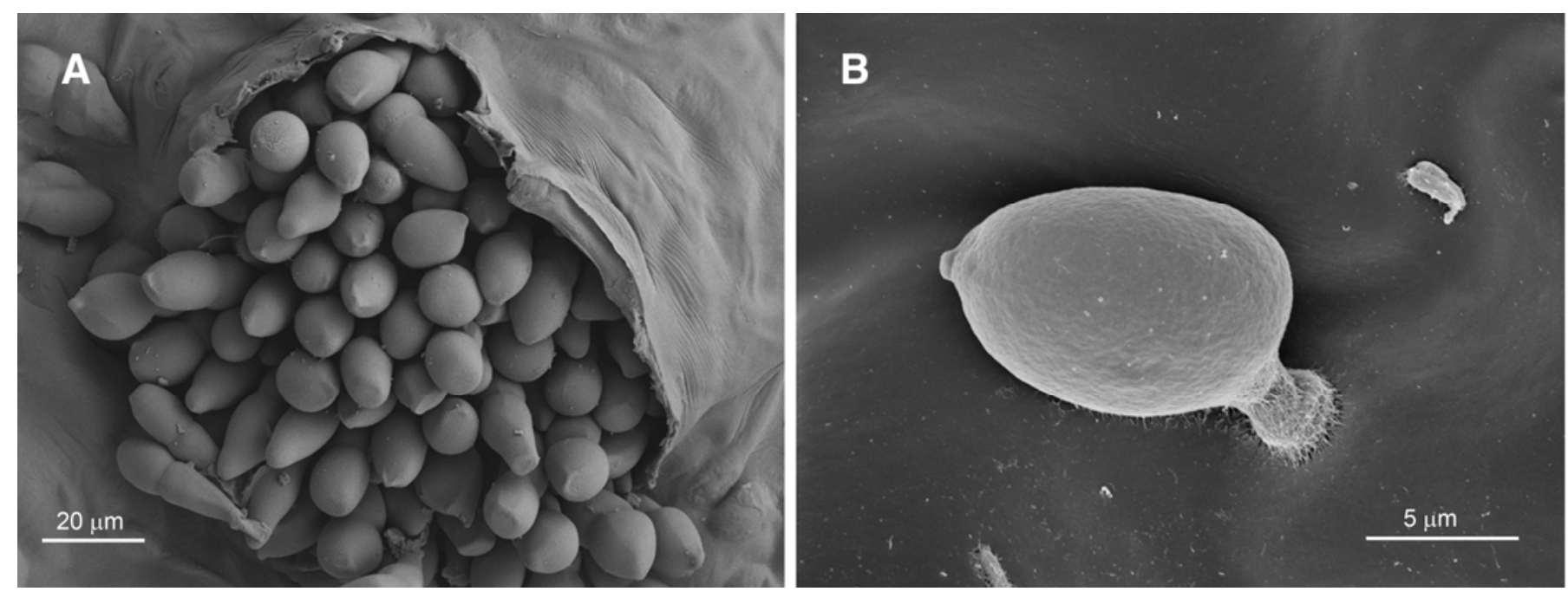

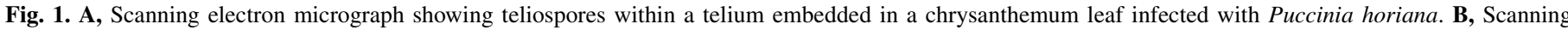

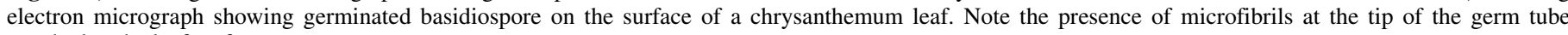
attached to the leaf surface. 


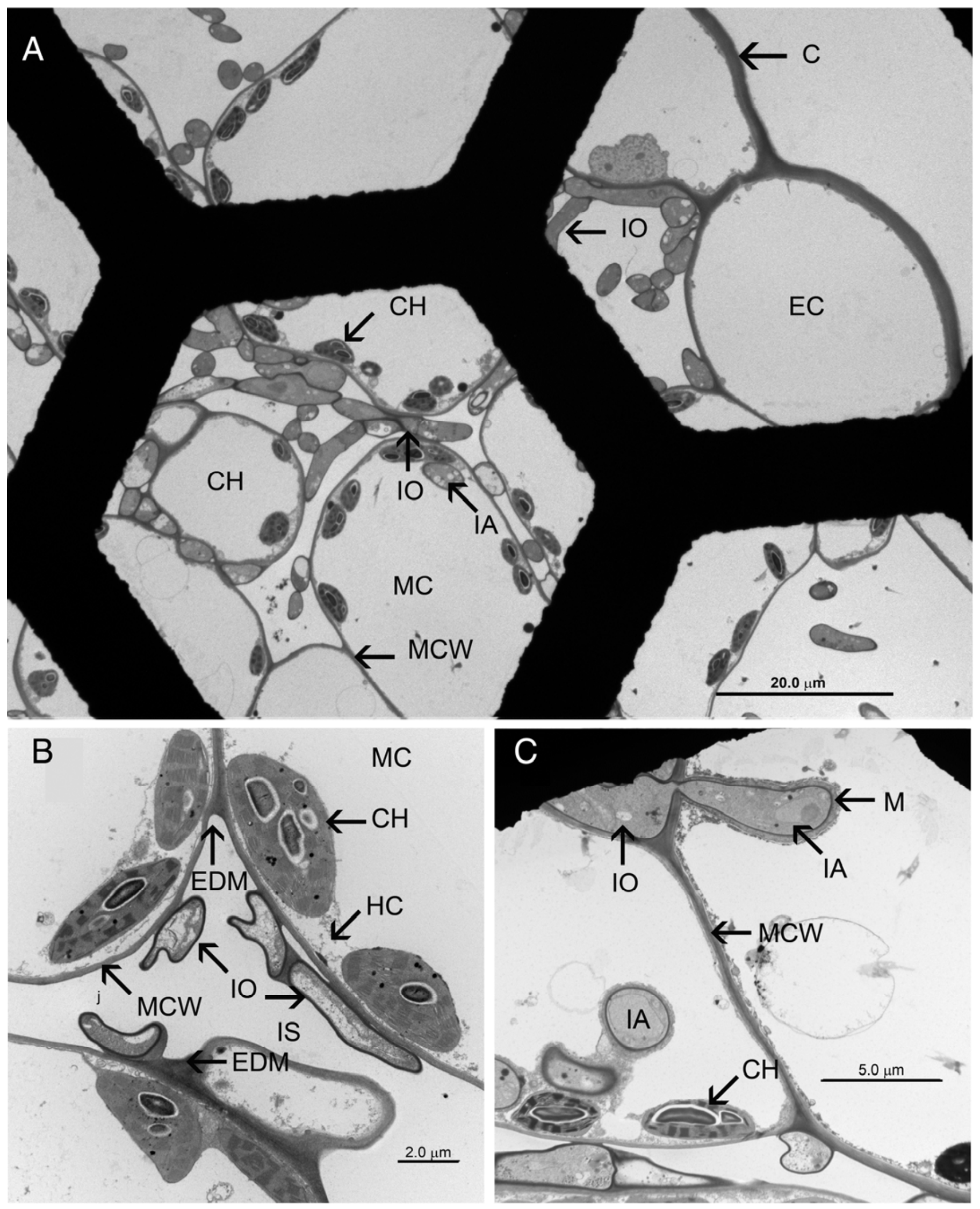

Fig. 2. A, Fungal cells in infected chrysanthmum leaf at time of initiation of pustule formation. At this stage, the fungus is mostly intercellular. B, Fungal hyphae in chrysanthemum leaf 36 days after inoculation. Note the presence of an electron dense material between the fungus and mesophyll cell. C, Penetration of a leaf mesophyll cell by Puccinia horiana in an intercellular space. Note the lack of deformation lines in the penetrated cell wall at the site of penetration suggesting that penetration is primarily by enzymatic digestion. The mesh supporting the leaf section is apparent at the upper left. $\mathrm{CH}=$ chloroplast, $\mathrm{C}=$ cuticle, $\mathrm{EDM}=$ electron dense material, $\mathrm{EC}=$ epidermal cell, $\mathrm{HC}=$ host cytoplasm, $\mathrm{IO}=$ intercellular hypha, $\mathrm{IA}=$ intracellular hypha, $\mathrm{IS}=$ intercellular space, $\mathrm{M}=$ matrix, $\mathrm{MC}=$ mesophyll cell, MCW = mesophyll cell wall. 
series, and infiltration with Spurrs low-viscosity embedding resin series. Then, 60- to 90-nm silver-gold sections of the tissue were sectioned on a Reichert/AO Ultracut microtome with a Diatome diamond knife and mounted onto 200-mesh Ni grids. Tissue sections were stained with $4 \%$ uranyl acetate and $3 \%$ lead citrate and viewed in an HT-7700 TEM Microscope (Hitachi High Technologies America, Inc.,) at $80 \mathrm{kV}$.

Light microscopy. Pieces of leaves, stems, and crowns from the overwintering experiment, and those grown in the greenhouse, were fixed for at least $24 \mathrm{~h}$ in a mixture of 2:1 absolute ethanol/ acetic acid, transferred to $0.1 M$ sodium phosphate buffer, $\mathrm{pH} 7.2$, rinsed twice with buffer, and dehydrated with a graded series of acetone. Plant pieces then were embedded in Spurr low viscosity embedding medium (Ladd Research Industries, Williston, VT) according to the manufacturer's directions. The pieces were trimmed and cross sectioned by means of a Leica RM 2245 microtome (Leica Microsystems Inc., Buffalo Grove, IL), stained $1 \mathrm{~min}$ in $0.1 \%$ cotton blue in lactophenol, and rinsed with water. The cross sections then were stained $1 \mathrm{~min}$ in lactofuchsin (26), rinsed in water, mounted in lactophenol, and observed by light microscopy at $\times 100$ and $\times 400$ magnifications.

\section{RESULTS}

Basidiospore germination and leaf penetration. Basidiospores, formed following germination of teliospores embedded in

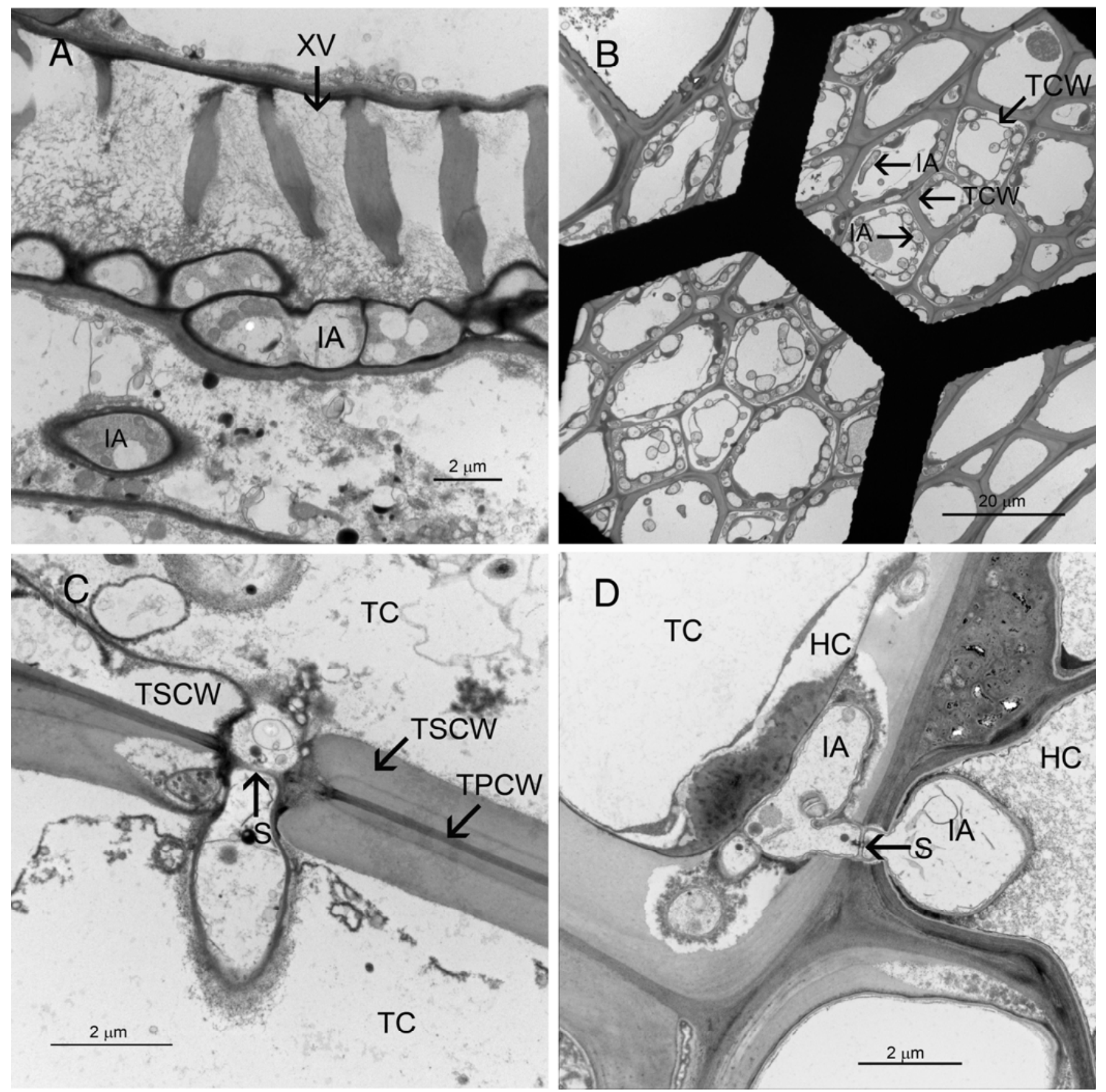

Fig. 3. A, Puccinia horiana hypha on the inside surface of a xylem vessel in chrysanthmum leaf vein. B, P. horiana in the crown region of a chrysanthemum plant. Note that the pathogen has colonized the secondary cell walls of tracheid cells throughout an extensive area of a vascular bundle. A portion of the bundle not infected is apparent at the lower right. C, P. horiana passing through a pit pair from one tracheid cell to an adjacent tracheid cell. Note that the portion of secondary cell wall at the upper left has been nearly completely dissolved. D, $P$. horiana passing from right to left through non-pitted area of tracheid cell walls. The cell to the right is a parenchyma cell, and thus has no secondary cell wall. $\mathrm{HC}=$ host cytoplasm, IA = intracellular hypha, $\mathrm{S}=$ septum, TC $=$ tracheid cell, $\mathrm{TCW}=$ tracheid cell wall, TPCW $=$ tracheid primary cell wall, TSCW = tracheid secondary cell wall, $\mathrm{XV}=$ xylem vessel. 
the leaf surface (Fig. 1A), were oval with a maximum length of approximately $10 \mu \mathrm{m}$ (Fig. 1B). Germination was by means of a single, short germ tube, usually about $3 \mu \mathrm{m}$ in length (Fig. 1B), extending from the basidiospore. At the site of leaf penetration, the tip of the germ tube appeared to attach to the surface of the leaf by microfibrils (Fig. 1B). Penetration of the leaf by the pathogen was directly through the cuticle, as shown by Firman and Martin (14).

Development of $\boldsymbol{P}$. horiana within leaves. The development of $P$. horiana in infected leaves was determined by examination of approximately 300 usable leaf cross sections by TEM. $P$. horiana hyphae grew both inter- and intracellularly (Fig. 2). Early growth was mostly intercellular (Fig. 2A and B). An electron-dense material formed at the interface between fungal and mesophyll cells, which suggested that the fungus had adhered to the surface of the host cells (Fig. 2B). Hyphae appeared to be highly variable in shape, often from 1 to $3 \mu \mathrm{m}$ in diameter (Fig. $2 \mathrm{~A}$ and B), but serial leaf cross sectioning will be required to confirm the shape of fungal hyphae. Penetration of mesophyll cells by $P$. horiana "penetration hyphae" appeared to be by enzymatic digestion of the host cell wall, indicated by total lack of deformation lines at the penetration sites (Fig. 2C). The pathogen also grew along the inside surface of xylem vessels within leaf veins (Fig. 3A).

Development of $\boldsymbol{P}$. horiana within the crown. Fungal hyphae were common in mature, and nearly mature, xylem tracheid cells, often replacing most of the tracheid cell wall contents (Fig. 3B). It was apparent that the contents of the tracheid cell walls in proximity to fungal hyphae became extensively digested (Fig.
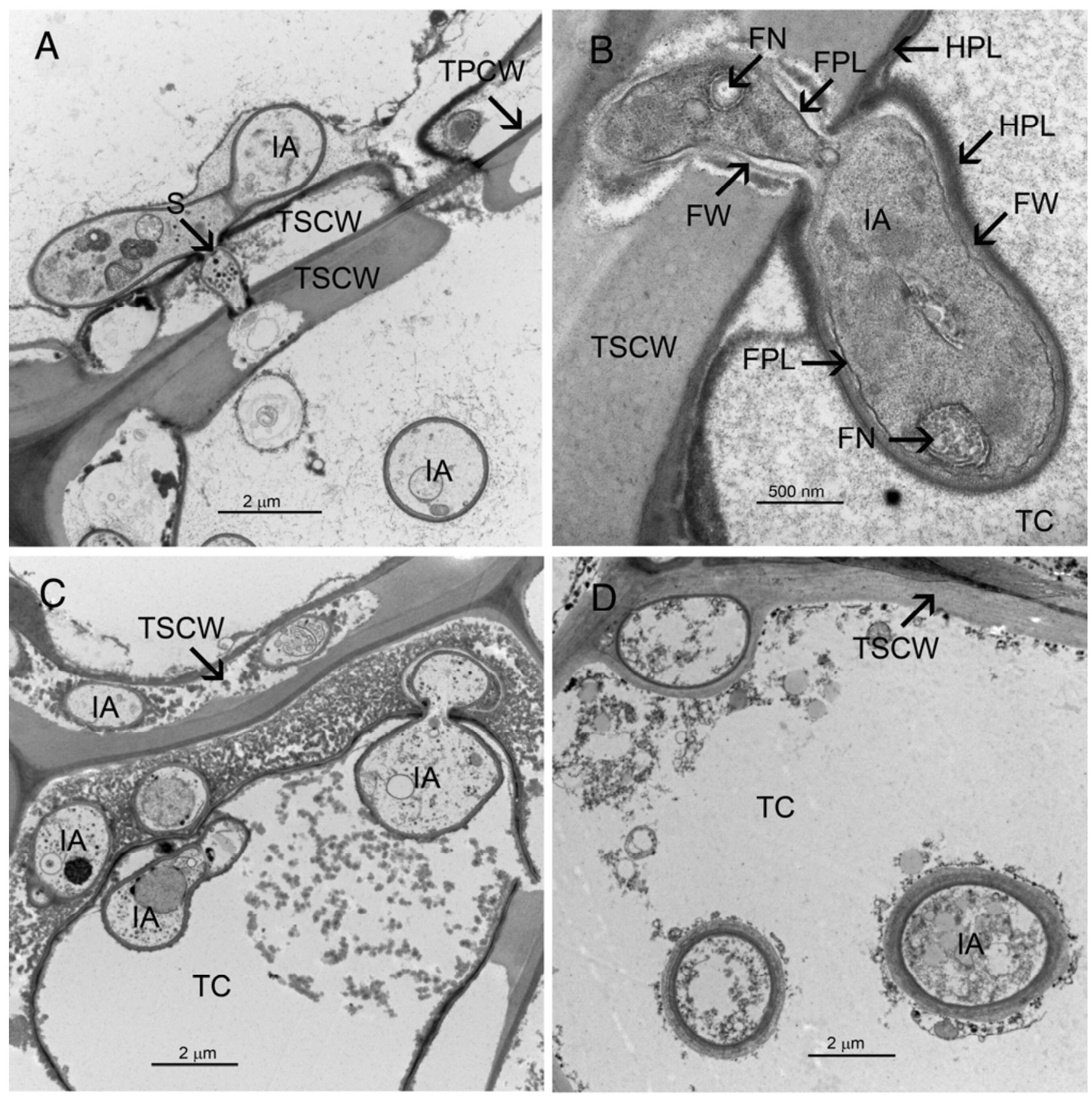

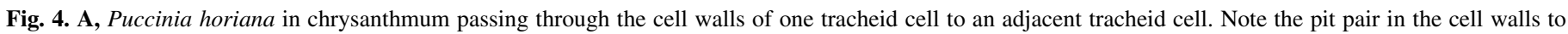

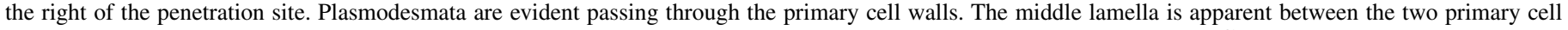

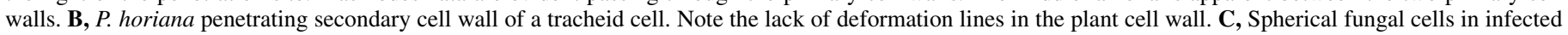

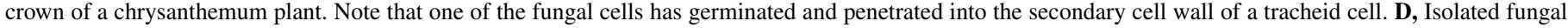

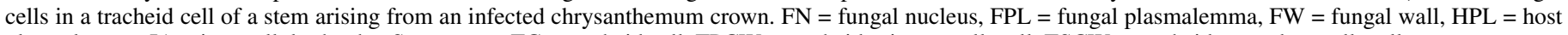
plasmalemma, IA = intracellular hypha, $\mathrm{S}=$ septum, TC = tracheid cell, TPCW = tracheid primary cell wall, TSCW = tracheid secondary cell wall. 
3B). The fungus frequently passed from one tracheid cell to an adjacent tracheid cell, either through a pit pair (Fig. 3C) or through a nonpitted area of the tracheid cell walls (Figs. 3D and 4A). Penetration often originated from the cytoplasm of one tracheid cell, through the walls of that cell, into an adjacent tracheid cell (Fig. 4A). Thus the pathogen passed through secondary and primary cell walls of the host. Penetration of tracheid cell walls appeared to be by enzymatic digestion as evidenced by the total lack of deformation lines in host cell walls at penetration sites (Fig. 4B and C). The presence of what appeared to be spherical fungal cells in the lumens of mature tracheid cells of infected crowns, and stems arising from infected crowns, suggested that the pathogen might be multiplying by budding (Fig. 4D). However, the identity and shape of the cells has yet to be confirmed.

The fungal plasmalemma appeared as a dark wavy line (Fig. 4B). To the outside of the plasmalemma was the fungal wall, which extended around the entire fungus thallus, including the penetration hypha (Fig. 4B). In some areas, the wall appeared to have separated from the plasmalemma (Fig. 4B). To the outside of the wall was the host cell cytoplasm, enclosed within a host plasmalemma (Fig. 4B). The fungus developed a septum at or near the point of entry into the tracheid cell wall (Figs. 3C and D and $4 \mathrm{~A}$ and B). Some areas of vascular bundles were severely affected by the pathogen, whereas other areas were completely devoid of the fungus (Fig. 3B).

Development of $P$. horiana within stems arising from infected crowns. Examination of tracheid cells in newly formed stems arising from infected crowns showed the presence of spherical cells similar to those in the crown (Fig. 4D). Leaves infected with $P$. horiana developed on these stems, suggesting that the plants were systemically infected (Fig. 5). The distribution of pustules on the leaf surface appeared to follow leaf veins (Fig. 5).

Confirmation of infection by light microscopy. Examination of leaves and crowns by light microscopy revealed the presence of

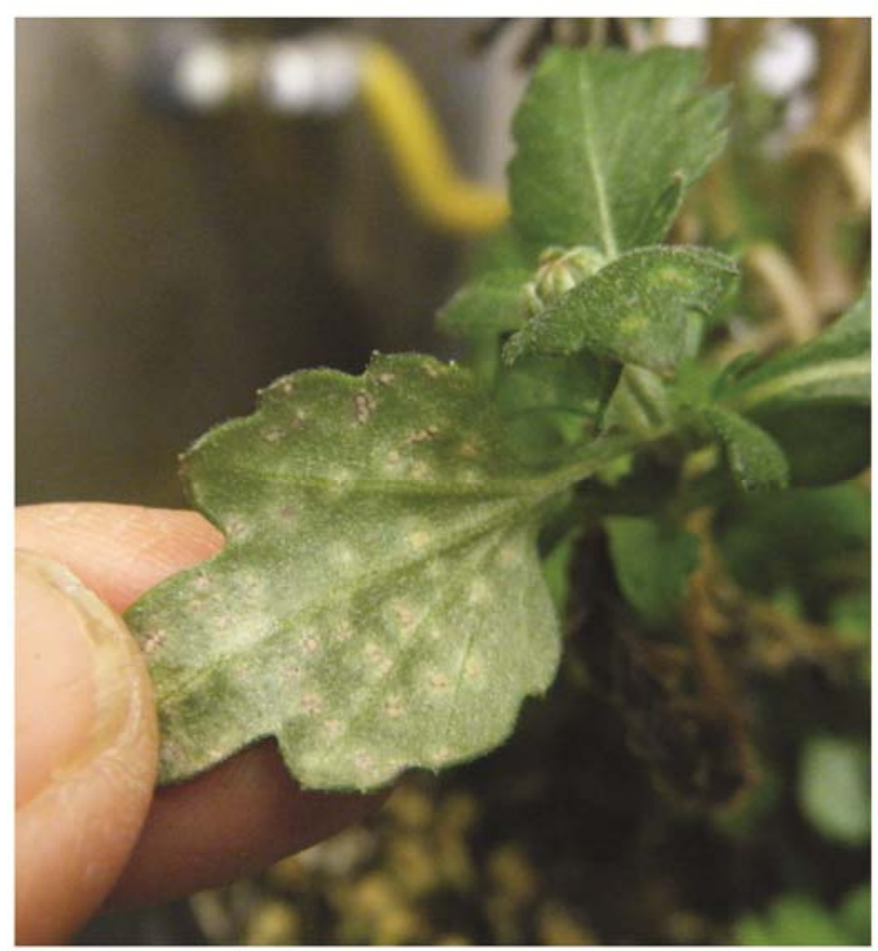

Fig. 5. Typical symptoms of chrysanthemum white rust on leaf of stem arising from the crown of an infected plant. The appearance of the pathogen in new leaves demonstrates the presence of systemic infection. the pathogen (Fig. 6). The fungus appeared as intercellular masses of dark blue hyphae in the leaf mesophyll and cortex of the crown (Fig. 6A and C). At later stages of infection in the leaf, there was considerable disruption of the host cells (Fig. 6A) as compared with noninfected leaf tissue (Fig. 6B). The pathogen was absent from noninoculated (control) plants. Although light microscopy was very beneficial for detecting the presence of the pathogen, it did not reveal the detail as shown by TEM.

\section{DISCUSSION}

In a previous study we determined that teliospores of $P$. horiana could not survive on or in soil in the greenhouse for more
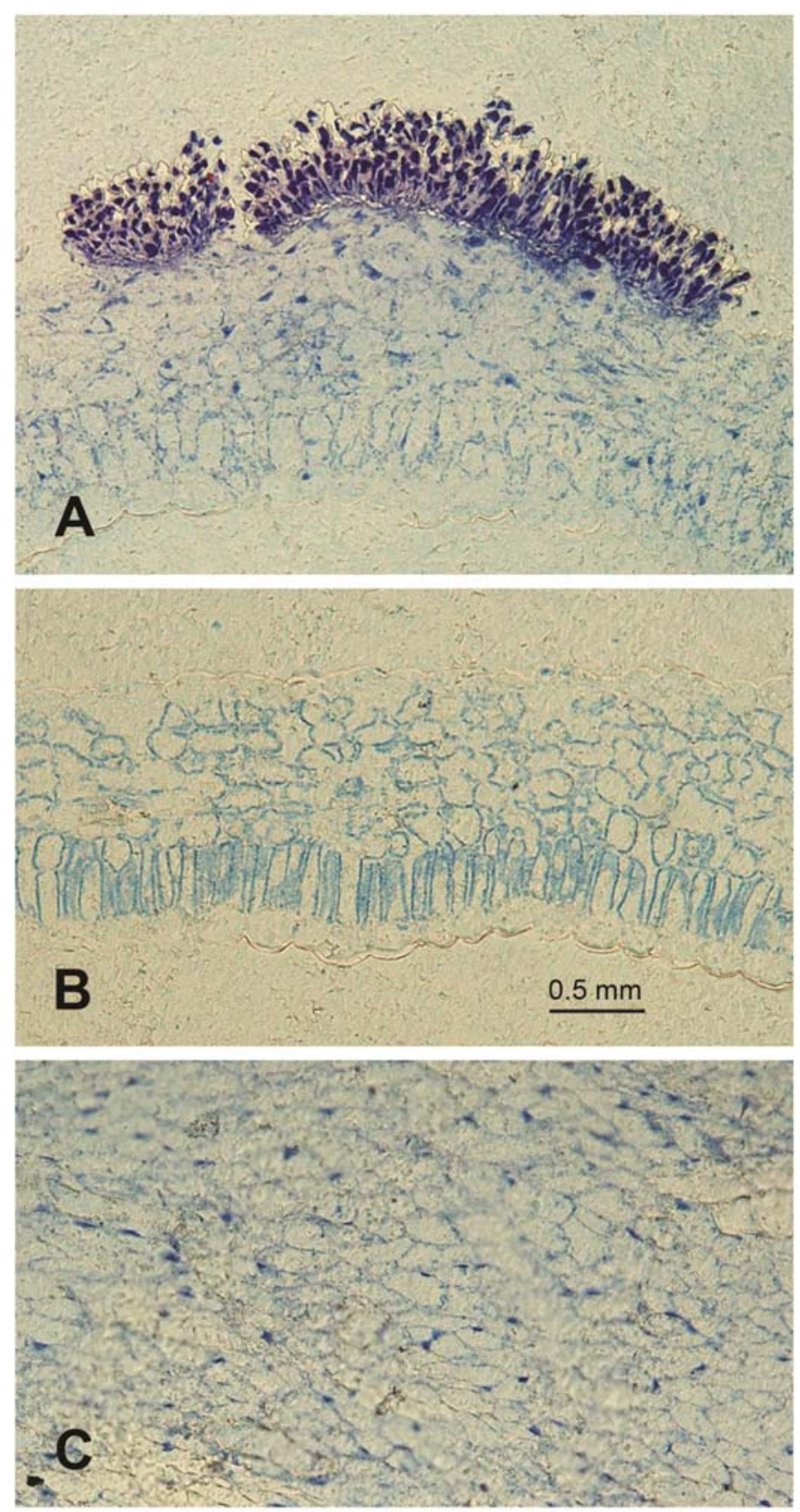

Fig. 6. Hyphae of Puccinia horiana in leaf and crown, and noninfected leaf for comparison, as observed by light microscopy. A, Cross section through chrysanthemum white rust pustule with teliospores erupting through the leaf surface. Note the dark blue stained areas consisting of fungus in the mesophyll tissue. Above the area with teliospores and at the extreme bottom is resin in which the tissue is embedded. B, Cross section through non-infected, control, leaf. C, Section through infected chrysanthemum crown showing dark blue staining fungus comparable to that in leaf mesophyll tissue in A. 
than approximately 5 weeks (6). Because teliospores in nature would have to pass through a period of temperatures similar to these greenhouse temperatures before the onset of winter, it appeared unlikely that, in nature, teliospores provided the means for survival from one year to the next.

As an alternative means of survival, we decided to determine whether the pathogen could survive as the result of systemic infection in plants. The detection of infection in and on new shoots following simulated winter suggested that the plants were systemically infected. Because inoculum of $P$. horiana was not present in the environment external to the plants before detection of infection on new growth, it was highly likely that the infection resulted from infection in the parent crowns. The distribution of pustules on the surface of leaves on infected crowns appeared to follow leaf veins (Fig. 5), unlike the more random distribution of pustules observed when leaves are infected by an external sporidial shower. Furthermore, because the study was conducted in a high-security plant disease containment facility without other chrysanthemum pathogens present, it is highly likely that the organism observed in the test plants was $P$. horiana.

Histological examination of the parent crowns confirmed the presence of the pathogen, which was not present in healthy plants. Although both light microscopy and TEM allowed detection of the pathogen, TEM was the more informative. TEM showed that $P$. horiana colonized tracheid cell walls of the crown and that penetration of cells was primarily by enzymatic digestion.

Systemic fungi ramify through plant tissues in several ways. With CWR, one possible way for the pathogen to reach the crown might be to grow down the stem by hyphal growth. Once in the crown, it is possible for a fungal pathogen to colonize the stem apical meristems and be carried along as the stem elongates, finally developing in new leaves. An alternative way to move into new stems and leaves from the crown is for the pathogen in colonized crown tissue to be carried up into new stems by means of the transpiration stream within xylem vessels.

Transport of fungal cells in xylem tissue was demonstrated in the American elm infected with Ophiostoma ulmi (Buism.) Nannf. (sensu lato) syn. Certocystis ulmi (Buis.) Moreau, the Dutch elm pathogen $(2,25)$. The fungus multiplied by budding, and these new cells were carried upward in vessels by the transpiration stream. Following artificial inoculation, movement into stem parts above the point of entry into xylem vessels occurred within minutes (25). The fungus was observed to spread from one tracheid cell to an adjacent tracheid cell by penetration of both tracheid secondary cell walls and intertracheary pit membranes (21). Once within vessels, $O$. ulmi was able to quickly move upward (21). Although there are obvious size and shape differences between elm trees and chrysanthemum plants, there are many similarities, including the presence of vessel elements. Infection in xylem vessels, having perforated plates at their ends, likely would require growth of the pathogen to pass from one vessel to another. Lateral movement from one tracheid cell to an adjacent tracheid cell would require penetration through tracheid cell walls, as observed in this study with chrysanthemum.

Systemic infection in chrysanthemum by $P$. horiana is not the only systemic infection caused by a rust pathogen. An extensively studied macrocyclic rust fungus that also causes systemic infection is $P$. puntiformis ( $P$. sauveolens, $P$. obtegens) on Canada thistle (Cirsium arvense (L.) Scop.) (22). Histological examinations of this fungus bear similarities to development of $P$. horiana $(6,22)$. Another rust pathogen, Puccinia thlaspeos, has been shown by means of molecular methods to systemically infect the biennial crucifer Dyer's woad, used in Europe for centuries to make a blue dye (20).

Several downy mildew pathogens, such as those that cause downy mildews of maize, sorghum, and pearl millet, also cause systemic infection in their hosts (3). With this latter group of pathogens, the fungus becomes established in stem meristematic tissues when the plant is less than 3 to 4 weeks old. In order for the pathogen to become systemic in its host, establishment in the apical meristem must be early in the development of the plant. All leaves that develop from then on are infected (3).

Numerous histological studies have been conducted to determine the development of rust pathogens following inoculation with urediniospores (12). However, little information exists on the development of rust fungi following inoculation with basidiospores. Urediniospores, being dikaryotic, give rise to dikaryotic hyphae within infected plant tissue. The dikaryotic hyphae develop mother cells that are appressed to the surface of host cells (16). Following penetration of host cells, D-haustoria are formed that are composed of a neck region that expands into the body of the haustorium (16). The wall of the haustorium is composed of an extrahaustorial matrix covered by an extrahaustorial membrane. Haustoria are believed to function as a means of obtaining nutrients from host cells $(10,16)$ and generally are relatively easy to recognize in infected plant tissue.

Monokaryotic hyphae, derived from monokaryotic spores such as basidiospores, do not produce D-haustoria. Their hyphae penetrate host cells by means of "penetration hyphae" and form intracellular hyphae within the penetrated cell (16). If the hyphae do not exit the penetrated cell, and thus are terminal on the hypha, they often are referred to as M-haustoria (16). They have little in common with D-haustoria but are believed also to function as a means of obtaining nutrients from the host cell. As with D-haustoria, they have been shown to have an extrahaustorial matrix (16).

As far as we are aware, this is the first report of observations by TEM of infection of a plant host by the monokaryotic phase of a rust pathogen. Development of the fungus therefore would not necessarily be analogous to that described for other pathogens. As expected, we did not observe D-haustoria; however, neither did we observe M-haustoria. Confirmation of the lack of the latter will require extensive histological examinations and serial sectioning of infected plant tissue.

Characteristically, $P$. horiana produced a penetration hypha which frequently penetrated from one tracheid cell to an adjacent tracheid cell (Figs. 3C and 4A), or tracheid cell to a parenchyma cell (Fig. 3D). We deduced the direction that the fungus grew based on examination of numerous penetrations at different stages in the penetration process. For example, in Figure 4A we believe that the pathogen grew from the plant cell at the upper left to the plant cell at the lower right. (Notice that the secondary cell wall in the cell to the lower right appears to be in the process of digestion. A spherical fungal cell is in the interior of the lower right cell. However, absolute proof of the shape of the cell requires serial sectioning.)

It was obvious from our study that the pathogen caused massive dissolution of host cell walls (Figs. 3C and 4C). In fact, dissolution was so extensive that it was hard to dismiss the probability that much of the nutrition of the pathogen was derived from host cell walls. Further studies are needed to determine the nature of this dissolution and the putative enzymatic components involved.

The number of plants used in this study was not sufficient to make an estimate of the frequency that systemic infection might occur following winter. In the study discussed here, four plants out of 24 became systemically infected. Future studies should examine the frequency with which chrysanthemum plants become systemically infected and whether a stimulus is required to induce systemic infection.

Chrysanthemum plants commonly survive through northeastern U.S. winters. The discovery that chrysanthemum plants, under at least some conditions, can become systemically infected suggests that systemic infection in chrysanthemum crowns may be a mechanism by which the fungus can survive the winters of northeastern United States. If this is found to be correct, then new 
disease control strategies may be required to control this important disease.

\section{ACKNOWLEDGMENTS}

Funding for this research was partially supported by the USDAAPHIS-CPHST through the FY2011 and FY2012 Farm Bills. Mention of trade names or commercial products in this publication is solely for the purpose of providing specific information and does not imply recommendation or endorsement by the U.S. Department of Agriculture. USDA is an equal opportunity provider and employer.

\section{LITERATURE CITED}

1. Baker, J. J. 1967. Chrysanthemum white rust in England and Wales 196366. Plant Pathol. 16:162-166.

2. Banfield, W. M. 1941. Distribution by the sapstream of spores of three fungi that induce vascular wilt disease of elm. J. Agric. Res. 62:637-681.

3. Bonde, M. R. 1982. Epidemiology of downy mildew diseases of maize, sorghum and pearl millet. Trop. Pest Manag. 28:49-60.

4. Bonde, M. R., Palmer, C. L., Luster, D. G., Nester, S. E., Revell, J. M., and Berner, D. H. 2014. Viability of Puccinia horiana teliospores under various environmental conditions. Plant Health Progress doi:10.1094/ PHP-RS-13-0117

5. Bonde, M. R., Peterson, G. L., Rizvi, S. A., and Smilanick, J. L. 1995. Myclobutanil as a curative agent for chrysanthemum white rust. Plant Dis. 79:500-505.

6. Buller, A. H. R. 1950. Puccinia sauveolens and its sexual process. Pages 345-383 in: Researches on Fungi. Vol. VII. The Sexual Process in the Uredinales. The University of Toronto Press, Toronto, Canada.

7. California Department of Food and Agriculture. 1991. Plant pathology highlights. Calif. Plant Pest Dis. Rep. (Oct.-Dec.) 10:87-89.

8. California Department of Food and Agriculture. 1992. Plant pathology highlights. Calif. Plant Pest Dis. Rep. (Jan.-May) 11:18-19.

9. California Department of Food and Agriculture. 1992. Plant pathology highlights. Calif. Plant Pest Dis. Rep. (June-Sept.) 11:36.

10. Calonge, F. D. 1969. Ultrastructure of the haustoria of intracellular hyphae in four different fungi. Arch. Mikrobiol. 67:209-225.

11. CMI Distribution Maps of Plant Diseases. 1989. Puccinia horiana map no. 403. CABI, Wallingford, UK

12. Edwards, H. H., and Bonde, M. R. 2011. Penetration and establishment of Phakopsora pachyrhizi in soybean leaves as observed by transmission electron microscopy. Phytopathology 101:894-900.

13. Exley, P. J., Giles, R. J., Pascoe, I. G., and Guy, G. L. 1993. The impact and control of white rust of chrysanthemums in Australia. Abstract 6th Int. Cong. Plant Pathol., National Research Council, Ottawa, Candada.

14. Firman, I. D., and Martin, P. H. 1968. White rust of chrysanthemums. Ann. Appl. Biol. 62:429-442.

15. Griesbach, J. A., Milbrath, G. M., and Thomson, T. W. 1991. First occurrence of chrysanthemum white rust caused by Puccinia horiana on florists' chrysanthemum in Oregon. Plant Dis. 75:431.

16. Harder, D. E., and Chong, J. 1984. Structure and physiology of haustoria. Chapter 14 in Volume I: The Cereal Rusts. W. R. Bushnell and A.P. Roelfs, eds. Academic Press, Inc., New York.

17. Hennings, P. 1901. Einige neue japanische Uredineen. Hadwigia 40:25-26.

18. Hiratsuka, N. 1956. Three species of chrysanthemum-rusts in Japan and its neighboring districts. Sydowia Ser. 2. Suppl. 1:33-34.

19. Kim, S. H., Olson, T. N., Nikolaeva, E. V., and Kang, S. 2011. Overwintering of chrysanthemum white rust caused by Puccinia horiana in Pennsylvania and challenges in its management. (Abstr.) Phytopathology 101(suppl.):S91.

20. Kropp, B. R., Hansen, D., Flint, K. M., and Thomson, S. V. 1996. Artificial inoculation and colonization of Dyer's Woad (Isatis tinctoria) by the systemic rust fungus Puccinia thlaspeos. Phytopathology 86:891-896.

21. MacDonald, W. L., and McNabb, H. S., Jr. 1970. Fine-structural observations of the growth of Ceratocysis ulmi in elm xylem tissue. BioScience 20:1060-1061.

22. Menzies, B. P. 1953. Studies on the systemic fungus Puccinia suaveolens. Ann. Bot. 17:551-569.

23. O'Keefe, G., and Davis, D. D. 2012. First confirmed report that Puccinia horiana, causal agent of chrysanthemum white rust, can overwinter in Pennsylvania. Plant Dis. 96:381.

24. Peterson, J. L., Davis, S. H., Jr., and Weber, P. V. V. 1978. The occurrence of Puccinia horiana on chrysanthemum in New Jersey. Plant Dis. Rep. 62:357-360.

25. Sinclair, W. A., and Campana, R. J. 1978. Dutch elm disease: Perspectives after 60 years. Plant Pathol. 1:5-52.

26. Tuite, J. 1969. Plant Pathological Methods. Burgess Publishing Co. Minneapolis, MN. 